\title{
Expression and Activity-Dependent Changes of a Novel Limbic-Serine Protease Gene in the Hippocampus
}

\author{
Zu-Lin Chen, ${ }^{1}$ Shigetaka Yoshida, ${ }^{1,2}$ Keiko Kato, ${ }^{1}$ Yoshiharu Momota, ${ }^{1}$, Jun Suzuki, ${ }^{1}$ Tatsuya Tanaka, ${ }^{2}$ Jiro \\ Ito, ${ }^{3}$ Hitoo Nishino, ${ }^{3}$ Saburo Aimoto, ${ }^{4}$ Hiroshi Kiyama, ${ }^{2}$ and Sadao Shiosaka' \\ ${ }^{1}$ Department of Structural Cellular Biology, Nara Institute of Science and Technology (NAIST), ${ }^{2}$ Biomedical \\ Research Center, Osaka University Medical School, ${ }^{3}$ Department of Physiology, Nagoya City University Medical \\ School, and ${ }^{4}$ Institute for Protein Research, Osaka University, Japan
}

\begin{abstract}
A novel murine cDNA which encodes a proteln designated neuropsin was cloned. Northern and in situ hybridization analyses demonstrated that neuropsin mRNA is expressed specifically in the limbic system of mouse brain and is localized at highest concentration in pyramidal neurons of the hippocampal CA1-3 subfields. Direct hippocampal stimulation and kindling induced by amygdaloid stimulation caused a significant bilateral change in neuropsin mRNA level in the hippocampal pyramidal neurons. The activity-dependent changes and the specific localization indicate that neuropsin is involved in hippocampal plasticity.

[Key words: serine protease, neuropsin, kindling, hippocampus, plasticity, tissue plasminogen activator, limbic system]
\end{abstract}

The hippocampus participates in various events associated with plasticity in the brain such as long-term potentiation (LTP; Kirkwood et al., 1993; Schuman and Madison, 1994) and depression (LTD; Dudek and Bear, 1992; Mulkey and Malenka, 1992), seizures, and kindling (McNamara, 1988). Recent studies have indicated that a rapid genomic response to neuronal stimulation plays a critical role in long-term facilitation in both vertebrates and invertebrates (Montarolo et al., 1986; Cole et al., 1989). Numerous candidates for plasticity-related genes including genes for a number of transcription factors have been cloned by screening of hippocampal cDNA libraries derived from mice, in which seizures or LTP had been induced (Nedivi et al., 1993; Qian et al., 1993; Worley et al., 1993). Stimulus-induced changes in levels of mRNA were also observed for protein kinases, GABA $A_{A}$ receptor $\beta_{1}$ isoform, c-fos, c-jun (Worley et al., 1993), and neurotrophic factors (Ernfors et al., 1991; Isackson et al., 1991; Dugich-Djorjevic et al., 1992; Mackler et al., 1992; Rocamora et al., 1992). Thus, numerous genes and macromolecular expression appear to be involved in hippocampal longterm information storage (Montarolo, 1986; Cole et al., 1989).

Some serine proteases are also considered to participate in

Received Oct. 27, 1994; revised Feb. 21, 1995; accepted Feb. 27, 1995.

Z.-L.C., S.Y., and K.K. made equal contributions to this study. We thank Prof. M. Tohyama for a critical review of the manuscript and Dr. Y. Kilou for helpful suggestions relating to the structure of the novel protein. We thank $\mathrm{A}$ Okabe, K. Sato, and A. Hirata for their technical assistance for electroencephalograms and imaging analysis. This work was supported by Grants-in-Aid from the Ministry of Education, Science and Culture of Japan

Correspondence should be addressed to Sadao Shiosaka, Ph.D., Department of Structural Cellular Biology, Nara Institute of Science and Technology, 8916-5 Takayama, Ikoma, Nara, 630-01 Japan.

Copyright $(c) 1995$ Society for Neuroscience $0270-6474 / 95 / 155088-10 \$ 05.00 / 0$ activity-dependent synaptic plasticity (Monard, 1988; Qian et al., 1993). Moreover, serine proteases might be essential for processing of physiologically active macromolecules, digestion of extracellular matrix proteins, and/or cleavage of synapse-relating proteins during axonal elongation, synaptic contact, synaptic adhesion, or de-adhesion (Monard, 1988; Pittman et al., 1989). Activity-induced changes in modification of morphology and number of spines and in modification of macromolecules may contribute to changes in synaptic efficacy (Bliss and Collingridge, 1993). However, no serine protease which is localized sitespecifically in the limbic system and is related to activity-dependent regulation of genomic response has yet been found. In the present study, to identify a hippocampal serine protease which might be involved preferentially in hippocampal functions, a series of reverse transcriptase-polymerase chain reactions (RT-PCRs) were performed using oligonucleotide primers based on well-conserved histidine and serine residues of serine proteases. Using the amplified sequence as a template, cDNAs for serine proteases which exclusively localizes in the limbic brain were screened by in situ hybridization histochemistry.

DDBJ accession number. The nucleotide sequence data reported in this article will appear in the GSDB, DDBJ, EMBL, and NCBI nucleotide sequence databases with following accession number D30785.

\section{Materials and Methods}

$R T$-PCR. Two oligonucleotide primers for PCR (shown in Fig. $1 A$ ) were synthesized based on the cDNA sequence for key regions of histidine and serine residues in the serine protease domain of nerve growth factor $\gamma$ subunit (NGF- $\gamma$; His ${ }^{65}$, Asp $^{120}$, Asp $^{207}$, Ser $^{213}$ ). Oligo-(dT)-selected hippocampal RNA ( $2 \mu \mathrm{g}$ ) was isolated from BALB/c mice (5 weeks old, male) with a Fast Track mRNA isolation kit (Invitrogen, CA) and reverse transcribed using random primers. The first strand was amplified with Taq DNA polymerase using the primers shown in Figure $1 A$. Conditions for PCR were $94^{\circ} \mathrm{C}$ for 2 min, followed by 40 cycles of $94^{\circ} \mathrm{C}$ for $1 \mathrm{~min}, 50^{\circ} \mathrm{C}$ for $2 \mathrm{~min}$, and $72^{\circ} \mathrm{C}$ for $3 \mathrm{~min}$, and then a final extension at $72^{\circ} \mathrm{C}$ for $10 \mathrm{~min}$. Fragments between 0.4 and $0.5 \mathrm{~kb}$ in size were recovered from pools of PCR products by agarose gel electrophoresis. The fragments were end-filled using the Klenow fragment and blunt end-ligated into pBluescript (II)KS + cut with HindIII/XhoI and endfilled with the Klenow fragment (Stratagene, La Jolla, CA). Transformation of the recombinant plasmids into DH5 $\alpha$ cells resulted in acquisition of 29 clones. Among these, ten clones and the reverse sequence of one clone were identical and represented the unidentified gene designated as B41.

Construction of hippocampal library. A murine hippocampal library was constructed in $\lambda$ gt10 with polyA-selected hippocampal RNA $(5 \mu \mathrm{g})$ using a Time Saver cDNA synthesis kit (Pharmacia, Sweden), and packaged using Gigapack II packaging extract (Stratagene).

Cloning of neuropsin. Approximately $4 \times 10^{5}$ plaques from the li- 
A.

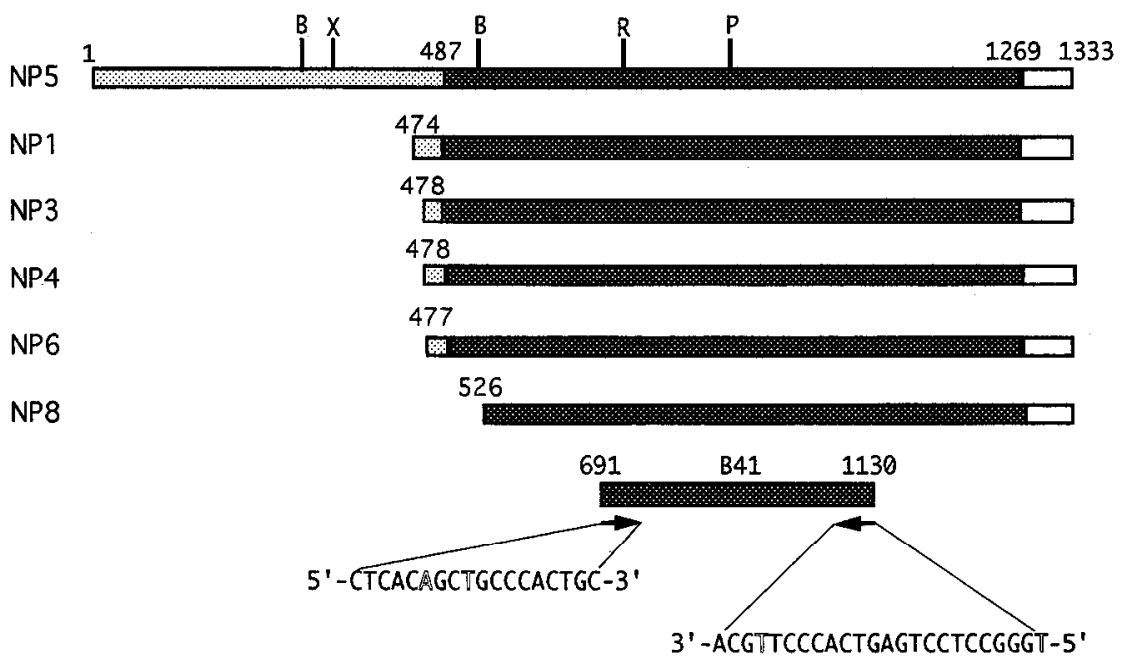

B.

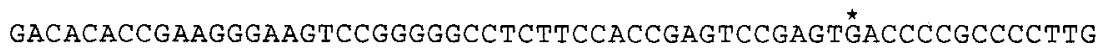

CATTCTGGAAGGT $\stackrel{ \pm}{ }$ GAGGCGAGAGGTCCCCAGACACGGACCTCAGGCGCAGGGAGGTCCC

CTTTCTCTGAGCCCAGGACCCTCCCACCCCCAGGCTCACATTCTTTCTCTCAGGATCTTC

AAGCGGGTCTCTTÄAGCTCCCTCTTCCCCAGGACGTTGGAGTCACAGCCTCAGATCTTTC

TCTCCAATCTCACAAGTGGGCCAGAACTCCTTTATAATGTCTGGATCCCCAACAGCAAGC

TCTCCCCCACACTÄAAATTCGGGGATCTAGAGCTCTGCCCTAGCTTTCTCAGCCCCTAGC

TCCATCCTCCAGCAAGACTCAAGACAGCTCCGGAAACACCTCCTTCCCCCAGTTCCCCAG

ACAACAAGATCTCAGGCTCCTCCCTCGGACTTCCTCTTAGTTCCACCCTCTTCCTCAGAG

GCCACCATGGGACGCCCCCCACCCTGTGCAATCCAGCCGTGGATCCTTCTGCTTCTGTTC

$\begin{array}{lllllllllllllllllllllllllll}M & G & R & P & P & P & C & A & I & Q & P & W & I & L & L & L & L & F\end{array}$

ATGGGAGCGTGGGCAGGGCTCACCAGAGCTCAGGGCTCCAAGATCCTGGAAGGTCGAGAG

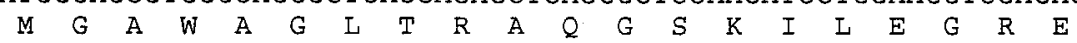

TGTATACCCCACTCCCAGCCTTGGCAGGCAGCCTTGTTCCAGGGCGAGAGACTGATCTGT

$\begin{array}{lllllllllllllllllllll}C & I & P & H & S & Q & P & W & Q & A & A & I & F & Q & G & E & R & L & I & C\end{array}$

GGGGGTGTCCTGGTTGGAGACAGATGGGTCFTCACGGCAGCCCACTGCAAAAAACAGAAG

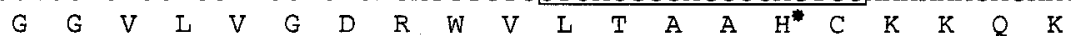

TACTCCGTGCGTCTGGGTGATCATAGCCTCCAGAGCAGAGATCAGCCGGAGCAGGAGATC

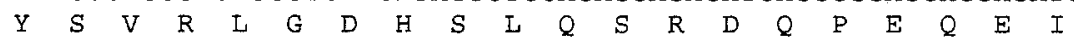

CAGGTGGCTCAGTCTATCCAGCATCCTTGCTACAACAACAGCAACCCAGAAGATCACAGT

$\begin{array}{llllllllllllllllllll}Q & V & A & Q & S & I & Q & H & P & C & Y & N & N & S & N & P & E & D & H & S\end{array}$

CACGATATAATGCTCATTCGACTGCAGAACTCAGCAAACCTCGGGGACAAGGTGAAGCCG

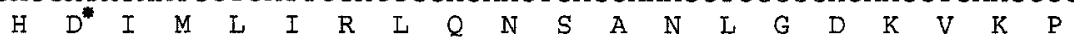

GTCCAACTGGCCAATCTGTGTCCCAAAGTTGGCCAGAAGTGCATCATATCAGGCTGGGGC

$\begin{array}{llllllllllllllllllllllllll}V & Q & L & A & N & L & C & P & K & V & G & Q & K & C & I & I & S & G & W & G\end{array}$

ACTGTCACCAGCCCTCAAGAGAACTTTCCAAACACCCTCAACTGTGCGGAAGTGAAAATC

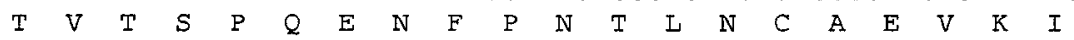

TATTCCCAGAACAAGTGTGAGAGAGCCTATCCAGGGAAGATCACCGAGGGCATGGTCTGT

$\begin{array}{llllllllllllllllllllllllllll}Y & S & Q & N & K & C & E & R & A & Y & P & G & K & I & T & E & G & M & V & C\end{array}$

GCTGGCAGCAGCAATGGAGCTGACACGIGCCAGGGTGACTCAGGAGGCCCTCTGGTGTGC

$\begin{array}{lllllllllllllllllllllllll}A & G & S & S & N & G & A & D^{*} & T & C & Q & G & D & S^{*+} & G & G & P & L & V & C\end{array}$

GACGGGATGCTCCAGGGCATCACCTCATGGGGCTCAGACCCCTGTGGGAAACCCGAGAAA

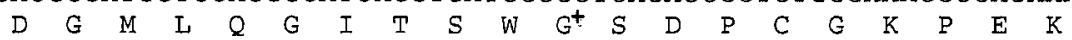

CCTGGAGTCTACACCAAAATCTGCCGCTACACTACCTGGATCAAGAAGACCATGGACAAC

$\begin{array}{llllllllllllllllllll}P & G^{+} & V & Y & T & K & I & C & R & Y & T & T & W & I & K & K & T & M & D & N\end{array}$

AGGGACTGATCCTGGTGTGTGTGTGGGGGGGGGGTTGTCAATAAACACCACCATTGGTTG
$\mathrm{R}$ *

GCAAAAAAAAAAA
Figure 1. A, Maps of neuropsin cDNA and B41. The sequences of the six clones (NP1,3-6,8) were combined to generate that of the full-length neuropsin cDNA. The dark-shaded area rcpresents the open reading frame. $B$, BamHI; $X, X h o \mathrm{I} ; R, R s a \mathrm{I} ; P, P s t \mathrm{I}$. Arrows represent oligonucleotide primers used in the present study, which were synthesized on the basis of the cDNA sequence for a region of histidine and serine residues of NGF- $\gamma$ important for its serine protease activity. Outlined letters represent mismatches between synthesized primers and the isolated neuropsin gene shown in $B . B$, Nucleotide and predicted amino acid sequences of neuropsin cDNA. The neuropsin cDNA is 1333 nucleotides in length. The underlined sequences $C C$ $A C C A T G G, N N S$ and AATAAA are Kozak's sequence, a putative glycosylation site, and a polyadenylation signal sequence, respectively. Amino acid residues marked with asterisks represent key amino acids of chymotrypsin-type serine proteases. + , Amino acid residues which can form an oxyanion hole; stars, stop codons. Two sequences corresponding to the primers shown in $A$ are boxed. 
brary were transferred to replicated filters (Hybond-N+; Amersham, USA) and hybridized in a buffer containing $5 \times$ SSPE, $2 \times$ Denhardt's solution, $0.1 \%$ SDS, $40 \%$ formamide, and $250 \mu \mathrm{g} / \mathrm{ml}$ denatured salmon testis DNA with $5 \times 10^{5} \mathrm{cpm} / \mathrm{ml}$ of ${ }^{32} \mathrm{P}$-labeled $\mathrm{B} 41$ probe prepared using random primers. Nine positive clones were obtained. Phage DNA isolated from each plate lysate of six clones was subcloned into pBluescripl(II)KS+ for sequencing and in situ hybridization.

Surgical procedures for direct electrical stimulation and kindling of mice. For direct electrical stimulation, 30 adult male ddY mice (11 weeks) were anesthetized with pentobarbital $(50 \mathrm{mg} / \mathrm{kg}$, i.p. $)$ and electrodes were placed in the ventral hippocampus (bregma $-2.5 \mathrm{~mm}$, lateral $3.5 \mathrm{~mm}$, and depth $3.0 \mathrm{~mm}$ from the surface of dura). Stimuli (400 $\mu \mathrm{A}, 10 \mathrm{~Hz}, 1 \mathrm{msec}$ square pulses for $10 \mathrm{sec}$ ) were delivered with an electric stimulator (Nihon Koden, Japan).

For kindling, 16 mice (ddY, 11 weeks) were anesthetized with pentobarbital, and an insulated stainless steel monopolar electrode was implanted stereotactically into the left amygdala (bregma $-2.0 \mathrm{~mm}$, lateral $3.0 \mathrm{~mm}$, and depth $4.5 \mathrm{~mm}$ from the surface of dura) for stimulation and recording. Following a 1 week recovery period, electrical stimulation was applied to the amygdala at $60 \mathrm{~Hz}$ with $450 \mu \mathrm{A}$ and $200 \mu \mathrm{sec}$ square pulses for $2 \mathrm{sec}$. Afterdischarge in cortical electroencephalograms was monitored, and the evoked behavioral seizures were classified according to a modification of Racine's standard criteria (Racine, 1972). Scores were as follows: stage 1, mouth and facial movement; stage 2 , forelimb clonus; stage 3 , forelimb clonus and tail up, and stage 4 , rearing and falling. The animals were stimulated once daily until they had exhibited three generalized seizures (stage 4 kindling). The mice were killed by decapitation $6 \mathrm{hr}$ after the last stimulation was applied. The control mice were not stimulated but wcrc otherwise treated identically in all respects.

Northern blotting. mRNA was isolated from the hippocampus and other tissues with an Invitrogen FastTrack kit. For Northern blotting, 1 $\mu \mathrm{g}$ of polyA mRNA was separated on formaldehyde-agarose gels and transferred onto nylon membranes (Hybond $\mathrm{N}+$, Amersham). Membranes were hybridized with probes labeled with ${ }^{32} \mathrm{P}$ by random priming, using cDNA inserts derived from clone NP5 (1.4 kb entire clone; probe 1) or a DNA fragment of the neuropsin gene separated by PCR as follows. Four portions of full-length neuropsin cDNA (NP5) were amplified by PCR to prepare four probes; that is, noncoding region of NP5 (1-486, probe 2), head of coding region of NP5 (187-690, probe 3), midcoding region corresponding to B41 (691-1130, probe 4), and tail of coding region of NP5 (1086-1266, probe 5) (compare Fig. 1A,B). Hybridization was performed overnight at $42^{\circ} \mathrm{C}$ in $0.75 \mathrm{M} \mathrm{NaCl}, 50 \mathrm{~mm}$ $\mathrm{NaH}_{2} \mathrm{PO}_{4}, 5 \mathrm{~mm}$ EDTA, $50 \%$ formamide, $5 \times$ Denhardt's solution. Blots were washed at high stringency $\left(0.3 \mathrm{M} \mathrm{NaCl}, 20 \mathrm{mM} \mathrm{NaH}_{2} \mathrm{PO}_{4}, 2 \mathrm{~mm}\right.$ EDTA, $2 \%$ SDS at $65^{\circ} \mathrm{C}$ ). Membranes were stripped and reprobed with cDNA from the ubiquitously expressed actin gene to examine relative amounts of RNA per lane. A mouse $\beta$-actin probe was purchased from Clontech (USA).

In situ hybridization histochemistry. The protocol for in situ hybridization histochemistry was based on the published method (Wanaka et al., 1990). Coronal sections $(20 \mu \mathrm{m}$ thick) from the mouse brain (ddY strain, three mice at each of $18 \mathrm{~d}$ embryo, postnatal days $1,10,20$, and adult) were cut on a cryostat and thaw-mounted onto slides coated with TESTA (Sigma, St. Louis, MO). Sections on slides were fixed in $4 \%$ formaldehyde in $0.1 \mathrm{M}$ phosphate buffer for $20 \mathrm{~min}$. After washing with phosphate buffer, the sections were treated with $10 \mu \mathrm{g} / \mathrm{ml}$ protease $\mathrm{K}$ in $50 \mathrm{~mm}$ Tris-5 mM EDTA (pH 8.0) for $5 \mathrm{~min}$ at room temperature, postfixed in the same fixative, acetylated with acetic anhydride in 0.1 $M$ triethanolamine, rinsed with phosphate buffer, and dehydrated through an ascending alcohol series. The ${ }^{35} \mathrm{~S}$-labeled RNA probes (antisense or sense) in hybridization buffer [ $50 \%$ deionized formamide, 0.3 M NaCl, 20 mm Tris-HCl, 5 mm EDTA, 10\% dextran sulfate, $1 \times$ Denhardt's solution, $0.2 \%$ sarcosyl, $250 \mu \mathrm{g} / \mathrm{ml}$ yeast tRNA, $400 \mu \mathrm{g} / \mathrm{ml}$ salmon testis DNA, and $20 \mathrm{~mm}$ dithiothreitol (pH 8.0)] werc placed on the sections, and then incubated at $55^{\circ} \mathrm{C}$ for overnight. The sections were washed at $65^{\circ} \mathrm{C}$ in $50 \%$ formamide, $2 \times \mathrm{SSC}, 10 \%$ 2-mercaptoethanol for $30 \mathrm{~min}$. Sections were then treated with $1 \mu \mathrm{g} / \mathrm{ml}$ RNase A in RNase buffer $[0.5 \mathrm{M} \mathrm{NaCl}, 10 \mathrm{mM}$ Tris-HCl, and $1 \mathrm{~mm}$ EDTA (pH 7.2)] for $30 \mathrm{~min}$ at $37^{\circ} \mathrm{C}$. Subsequently, sections were incubated at $65^{\circ} \mathrm{C}$ in $50 \%$ formamide, $2 \times \mathrm{SSC}, 10 \% 2$-mercaptoethanol for $30 \mathrm{~min}$ and then rinsed with $2 \times \mathrm{SSC}$ and $0.1 \times \mathrm{SSC}$ for $10 \mathrm{~min}$ at room temperature, dehydrated through an ascending alcohol series, and air dried.

In situ hybridization histochemistry with the zif 268 synthetic oligoprobe was performed according to the protocol described in our pre- vious article (Sekitani et al., 1990). An antisense zif268 oligonucleotide probe (45-mer) was synthesized according to Wisden et al. (1990).

Slides after hybridization reactions were coated with $\mathrm{K}-5$ emulsion (Ilford, UK) and exposed for 3 weeks. Once developed in D-19 developer (Kodak, USA), the sections were then observed under a light microscope with dark-field illumination or double dark- and bright-field illumination.

Imaging analysis. The sections after in situ hybridization were exposed to $\mathrm{x}$-ray film or imaging plates, in place of autoradiographic emulsion. Computerized image analysis systems (Argus 100, Hamamatsu Photonicus, Hamamatsu, Japan; BAS2000, Fuji Photo Film, Japan) were used for quantification of signal densities on autoradiograms.

\section{Results}

RT-PCR to identify serine protease homologous cDNAs

The two oligonucleotide primers for RT-PCR shown in Figure $1 A$ were synthesized based on the cDNA sequence of regions of histidine and serine residues, the key amino acids in the serine protease domain of NGF- $\gamma\left(\mathrm{His}^{65}, \mathrm{Asp}^{120}, \mathrm{Asp}^{207}, \mathrm{Ser}^{213}\right.$ ). Using hippocampal mRNA as a template, we identified and analyzed sequences of 29 RT-PCR products subcloned into pBluescript(II) $\mathrm{KS}+$. A homology search in the GeneBank database revealed that 12 clones encoded tissue plasminogen activator (tPA), 11 clones represented the same unidentified gene tentatively designated B41 (439 bp), and 6 clones encoded three other kinds of unidentified molecules. No gene for NGF- $\gamma$ was identified from the hippocampal mRNA. Thus, the hippocampus appeared to produce a low level of NGF- $\gamma$ or none at all, although a high level of preproNGF- $\beta$ mRNA is present (Isackson et al., 1991; Rocamora et al., 1992). The nucleotide sequence of B41 showed $32,40,47$, and $50 \%$ homology to the serine protease domains of the genes for NGF- $\gamma$ (Evans and Richards, 1985), epidermal growth factor-binding protein (EGFbp; Blaber et al., 1987), tPA (Rickles et al., 1989), and NGF- $\alpha$ (Evans and Richards, 1985), respectively.

\section{Cloning and structure of neuropsin cDNA}

A murine hippocampal library was constructed in $\lambda \mathrm{gt} 10$ as described in Materials and Methods, and then screened with a B41 cDNA fragment (439 bp) obtained by RT-PCR. Six positive clones (NP1,3-6,8 in Fig. $1 A$ ) were obtained by screening about $4 \times 10^{5}$ plaques. A full-length cDNA (NP5) was isolated which encoded a novel protein, which we designated "neuropsin" in reference to its sequence homology to that of trypsin (Fig. 2) and its extensive expression in neuron (see below). The NP5cDNA (Fig. 1A,B) was 1333 base pairs (bp) long, with a 780 bp open reading frame that started with an ATG triplet at position 487, followed by a second ATG triplet at position 541 . This open reading frame has the potential to encode a protein of 260 amino acids (Fig. $1 B$ ). Translation might be initiated at either of the two ATG codons. However, the former ATG was included within Kozak's sequence (CCACCATGG) (Kozak, 1986), and thus, translation of neuropsin probably starts at the first ATG (Fig. 1B, underlined nucleotides). The 3' noncuding region contained a poly $\mathrm{A}^{+}$sequence and a putative polyadenylation signal sequence, AATAAA, which was located at a site 18 nucleotides upstream from the polyA ${ }^{+}$sequence (Fig. 1B). cDNA sequences of the other five clones (NP1,3,4,6, and 8) perfectly overlapped that of NP5 cDNA. The primers derived from NGF- $\gamma$ had four nucleotide mismatches to the cloned neuropsin cDNA corresponding regions (Fig. 1A, outlined letters in the oligonucleotide sequences). 


\author{
NP \\ NGF- $\gamma$ subunit \\ NGF- $\alpha$ subunit \\ EGFbo \\ Trypsin
}

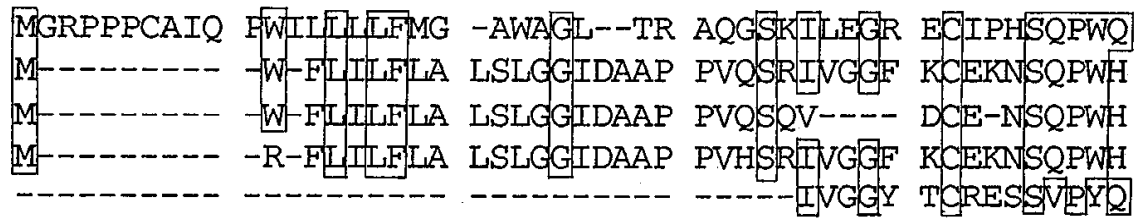
15

\section{NP}

NGF- $\gamma$ subunit NGF- $\alpha$ subunit EGF'bP Trypsin

\section{NP}

NGF- $\gamma$ subunit NGF- $\alpha$ subunit EGFbp Trypsin

NP NGF- $\gamma$ subunit NGF- $\alpha$ subunit EGFbp Trypsin

NP NGF- $\gamma$ subunit NGF- $\alpha$ subunit EGF'bp Trypsin
A ALFOGERII CGGVLVGDRW VLTAAHCKXKQ KYISVRLGDHS ILSRDQPEQE VAVYRYTQYL CGGVLLDPNW VLTAAHCYDD NYYKVWLGKNN IFKDEPSAOH VAVYRFNKYO CGGVLLDRNW VLTAAHCYND IXYQVWLGINNN FLEDEPSDQH VAVYRYNEYI CGGVLEDANN VLTAAHCYYE ENNKMSLGKNN LYEEEPSAOH VSTNAGYHF- CGGSLTNDOW VVSAAHCY XIX RIOVRLGEHN INVLEGNEOF
97 89 84 89 64

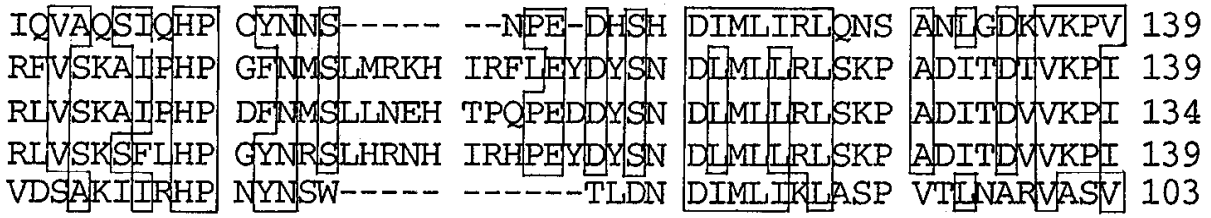

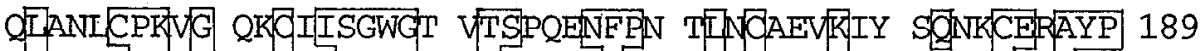

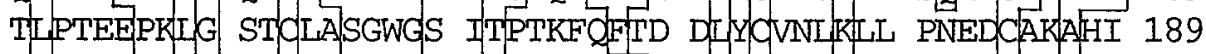
TLPTEEPKLG STOLASGWGS TTPIKFKYPD DLLOVNLKLLI PNEDCDKAAHE 184 ATPTEEPKIG STOLASSGWS TTPFKFONAK DIOOVNLKLI PNEDCGKAHI 189

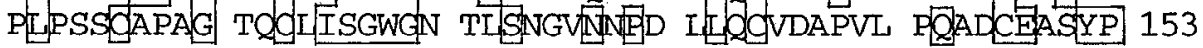

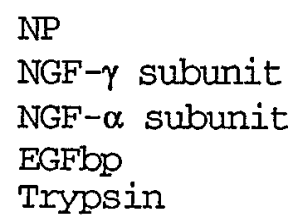

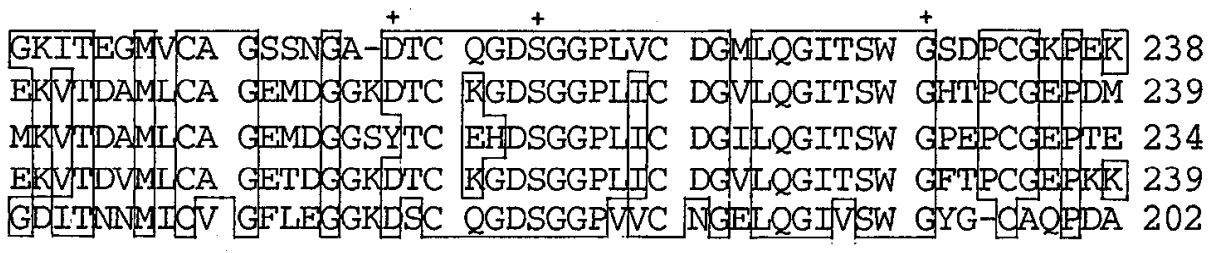

\begin{tabular}{|c|c|}
\hline PGVYTKICRY TITIKKTMDN RD & 26 \\
\hline PGVYTKLNKF TISWIKDTMAK NE & \\
\hline PSWYTKLIKF SSWIRETMMAN NE & \\
\hline $\begin{array}{l}\text { PGVYTKLIKF TSSWIKDTMAK NL } \\
\text { PGVYTKVONY VDWIONITAD N- }\end{array}$ & \\
\hline PGVYIKMUNYY VLWDENILIAD & \\
\hline
\end{tabular}

Figure 2. Comparison of sequences of neuropsin and other serine proteases. Perfectly conserved amino acids are boxed. I, Amino acid residues which can form an oxyanion hole, which are well-conserved between active serine proteases (NGF- $\gamma$ subunit, EGFbp, and trypsin), but not in a nonactive enzyme, the NGF- $\alpha$ subunit. $N P$, Neuropsin; $N G F$, nerve growth factor; $E G F b p$, epidermal growth factor-binding protein.

Sequence comparison of serine proteases

Alignment of the predicted amino acid sequence of neuropsin with those of other serine proteases is shown in Figure 2. The GENE WORKS alignment program (Intelli Genetics, Mountain View, CA) and the DNA Data Bank of Japan (DDBJ), GeneBank, EMBL, and SwissProt databases were used to generate these comparisons. The prosite motif was predicted by reference to Brenner (1988) and Marshall (1972). Neuropsin exhibited approximately $43 \%$ identity to EGFbp, $41 \%$ identity to NGF- $\gamma$,
$39 \%$ identity to NGF- $\alpha, 38 \%$ identity to trypsin, and $18 \%$ identity to tPA protein in full amino acid sequence (Fig. 2). The key amino acid residues of serine proteases are also contained in neuropsin, that is, $\mathrm{His}^{73}$, Asp ${ }^{120}$, and $\mathrm{Ser}^{212}$ (Fig. 1B, shown by asterisks). The predicted neuropsin seems also to form an oxyanion hole, which may be required for the interaction of the protease with its substrate. Asp ${ }^{206}, \mathrm{Ser}^{212}$, Gly ${ }^{224}$, and Gly ${ }^{234}$ may form this hole in neuropsin and these residues are identical to the corresponding residues in trypsin (Fig. 2, shown by + ) 

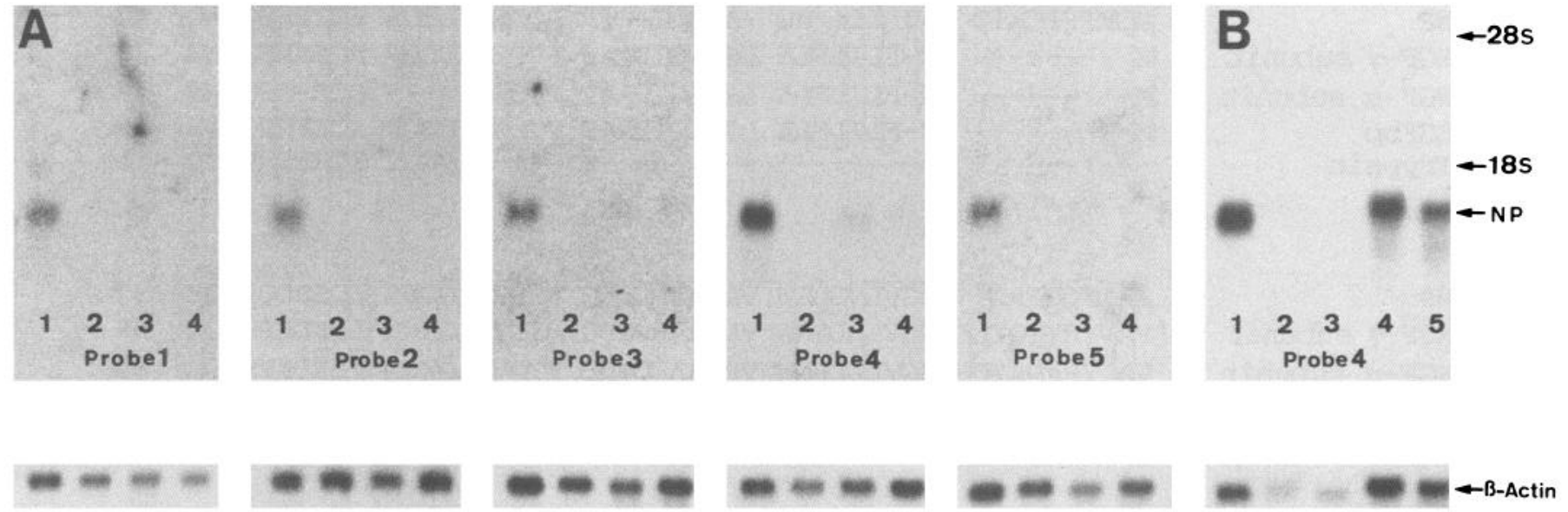

Figure 3. Northern blot analysis of mRNA isolated from brain $(A)$ and various tissues $(B)$. Approximately $1 \mu \mathrm{g}$ of polyA mRNA was loaded per lane. Full-length (NP5) and four partial neuropsin cDNAs were labeled with ${ }^{32} \mathrm{P}$ and used as probes. Probe 1, 1-1333 (NP5, full-length); Probe 2, 1-486 (noncoding region of NP5); Probe 3, 487-690 (coding region of NP5); Probe 4, 691-1130 (coding region of NP5); Probe 5, 1086-1266 (coding region of NP5). An mRNA of approximately $1.4 \mathrm{~kb}$ was specific to the hippocampus and was detected by full-length (Probe 1 ) and all four partial cDNA probes (Probes 2-5). A:Lane 1, hippocampus; lane 2, cerebellar cortex; lane 3, cerebral cortex; lane 4, olfactory bulb. B:Lane 1 , hippocampus; lane 2, muscle; lane 3, liver; lane 4, lung; lane 5, spleen. The positions of ribosomal RNAs are indicated on the right. Hybridization with a $\beta$-actin probe (Clontech) demonstrated that equivalent amounts of RNA were loaded per lane. $N P$, neuropsin mRNA; $\beta$-Actin, $\beta$-actin mRNA.

(Madison et al., 1993). Furthermore, a putative glycosylation site, Asn-Xaa-Ser, is located at amino acid residues 110-112. A glycosylation site Tyr-Asn-Asn-Ser-Asn has been found in several kallikrein-type serine proteases (YNNSN; Fig. 1B). In addition, a hydropathy plot constructed by the method of Kyte and Doolittle (1982) indicated that neuropsin contains a highly hydrophobic region at its $\mathrm{N}$ terminus.

\section{Northern blotting}

Northern blot analysis demonstrated that full-length (Probe 1) and four partial neuropsin probes (Probes 2-5) all hybridized to only one RNA transcript derived from the hippocampus (Fig. $3 A$ ); a mRNA of approximately $1.4 \mathrm{~kb}$, determined in reference to the mobilities of $18 \mathrm{~S}$ and $28 \mathrm{~S}$ rRNA. Weak corresponding bands were observed in the cerebral cortex (lane 3 ) and olfactory bulb (lane 4) when the probes 4 was used as hybridization probe, but not in the cerebellar cortex of adult mice indicating that this area contains levels of neuropsin mRNA below the limit of detection by Northern blotting (Fig. $3 A$ ). The corresponding bands $(1.4 \mathrm{kDa})$ were also observed in lung and spleen (Fig. $3 B$ ).

\section{Limbic-specific localization of neuropsin $m R N A$}

Histological localization of neuropsin mRNA in the mouse brain was examined by in situ hybridization histochemistry using the coding region (B41) of the neuropsin gene. Neuropsin mRNA was expressed exclusively in the limbic areas of the brain, with the most intense hybridization signals in the CA1-3 subfields $(\mathrm{H}$; Fig. $4 A, B, D)$. The CA2 subfield showed rather less intense hybridization than the other subfields. The silver grains were clearly localized on the pyramidal neurons in the CA1-3 subfields when observed under a microscope equipped with a double-illumination condenser (Fig. 4B,D). A high density of hybridization-positive signals was found in the lateral amygdaloid nucleus (Fig. 4A). In the frontal cerebral cortex, a great number of faintly labeled neurons were scattered in layers II, IV, and V of areas 1-3 and the cingulate cortex. The hybridization signals in the cingulate cortex continued posteriorly into the retro-splenial granular cortex and presubiculum (Fig. $4 E$ ). The anterior ol- factory nuclei, lateral septal nucleus, pars dorsal, medial septal nucleus, and vertical and horizontal diagonal bands were also labeled with the neuropsin probe (Fig. $4 E, F$ ). Ontogenetic observations showed the appearance of neuropsin gene in $18 \mathrm{~d}$ embryos and a similar distribution pattern throughout neonatal to adult development (data not shown).

No signals were observed in adjacent sections hybridized with the corresponding sense probe, demonstrating that the riboprobe was highly specific for the neuropsin gene (Fig. $4 C$ ). The in situ hybridization and Northern analysis data described above showed that neuropsin gene expression is highly restricted to the neuronal elements of the limbic brain.

\section{Effects of electrical stimulation on neuropsin gene expression}

The neuron- and site-specific localization of neuropsin gene expression in the hippocampal CA1-3 subfields suggested that this molecule might be related to the plasticity of pyramidal neurons in the hippocampus. Thus, we examined the effects of direct hippocampal stimulation on neuropsin gene expression by quantification of in situ hybridization signals. After hippocampal stimulation $(400 \mu \mathrm{A}, 1 \mathrm{msec}$ square pulses at $10 \mathrm{~Hz}$ for $10 \mathrm{sec})$ of the CA3 subfield of the ventral hippocampus (bregma -2.5 $\mathrm{mm}$, lateral $3.5 \mathrm{~mm}$, and depth $3.0 \mathrm{~mm}$ ), the level of expression of neuropsin decreased ipsilaterally for 3-12 hr; the reduction relative to sham-operated controls was significant as determined by Student's $t$ test $(P<0.05$; Fig. $5 A, F)$. The maximum decrease was equivalent to a $38 \%$ reduction at the level of the ipsilateral CA1 subfield. A reduction was apparent in the CA1 subfield but was not observed in the CA3 subfield (Fig. 5A-C, shown by arrows). Such a reduction was also found on the side contralateral to stimulation (Fig. 5A).

By in situ hybridization histochemistry specific for tPA and zif268 mRNA and sections adjacent to those examined for neuropsin mRNA, we found that the levels of expression of these genes were also elevated in the dentate gyrus immediately after stimulation (Fig. 5D,E). This finding was in good agreement with those of earlier studies which demonstrated induction of tPA and zif 268 by seizures, kindling, and long-term potentiation 

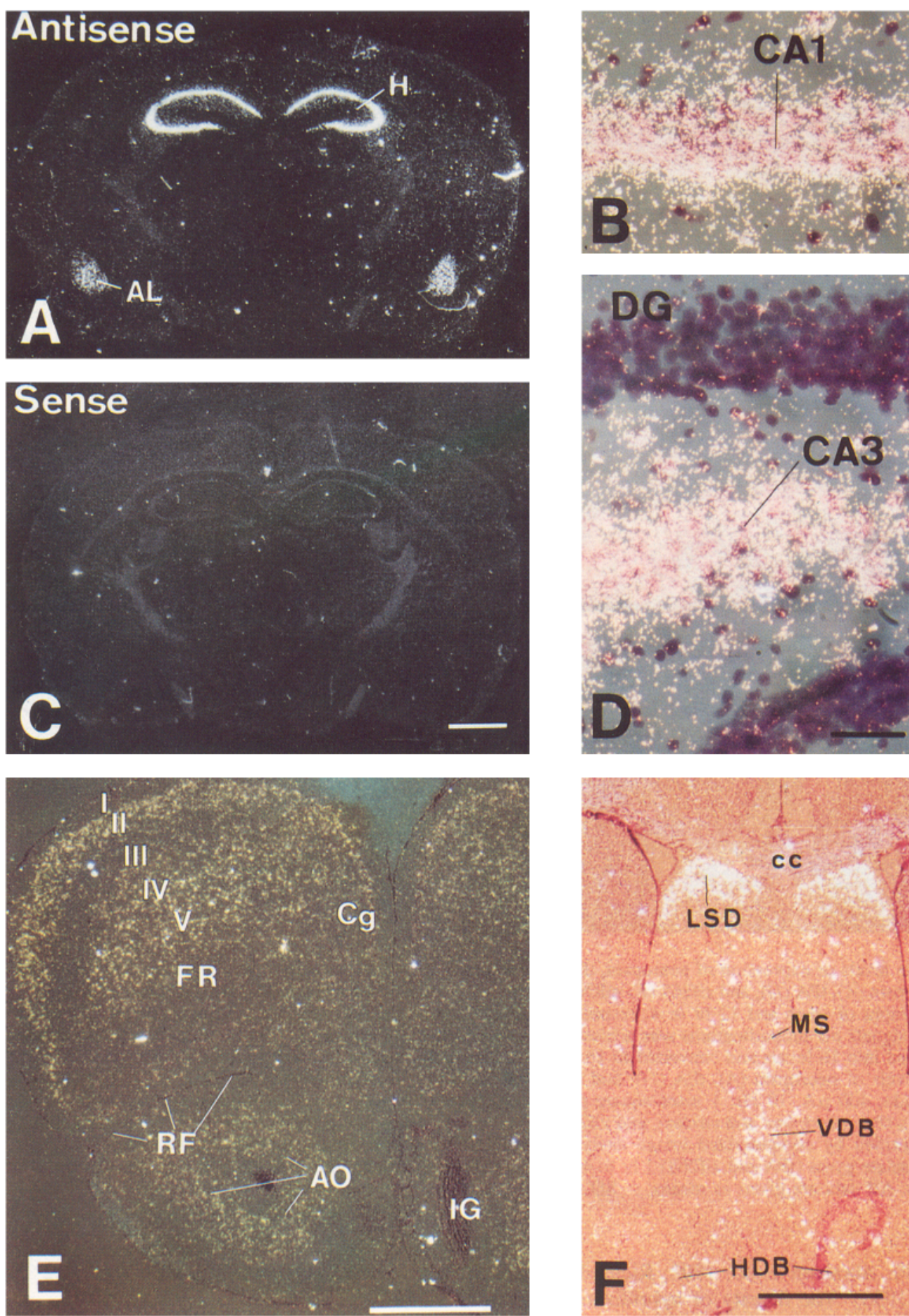

Figure 4. Expression of neuropsin mRNA in neurons of limbic areas. Frontal sections demonstrate results of in situ hybridization using an antisense and a control sense riboprobe. Probe 4 (B41) was used for in situ hybridization histochemistry. A, Hippocampal CA1-3 subfields (H) and the lateral amygdaloid nucleus $(A L)$ hybridized with the probe 4 antisense riboprobe. Intense hybridization signals were observed as silver grains under dark-field illumination. $B$, High-magnification photograph with dark- and bright-field double illumination showing intense hybridization signals in the pyramidal neurons in CA1. Clusters of silver grains clearly observed under dark-field illumination were layered upon neuronal cell bodies counter stained with thionin. $C$, An adjacent section hybridized with the control probe 4 sense riboprobe. $D$, Photograph of CA3 pyramidal neurons observed by double dark- and bright-field illumination. Note that no silver grains were observed on the granular layer of the dentate gyrus $(D G)$. $E$, Dark- and bright-field micrograph of frontal cerebral cortex $(F R)$ and anterior olfactory nuclei $(A O)$. $I-V$, Layers of the frontal cortex, areas $1-$ 3. $C g$, Cingulate cortex. $F$, Dark- and bright-field micrograph showing hybridization signals in the lateral septal nucleus, pars dorsal $(L S D)$, medial septal nucleus $(M S)$, and vertical and horizontal diagonal band $(V D B$ and $H D B)$, respectively. Scale bars: $C, E$, and $F, 1 \mathrm{~mm} ; D, 50 \mu \mathrm{m}$. 

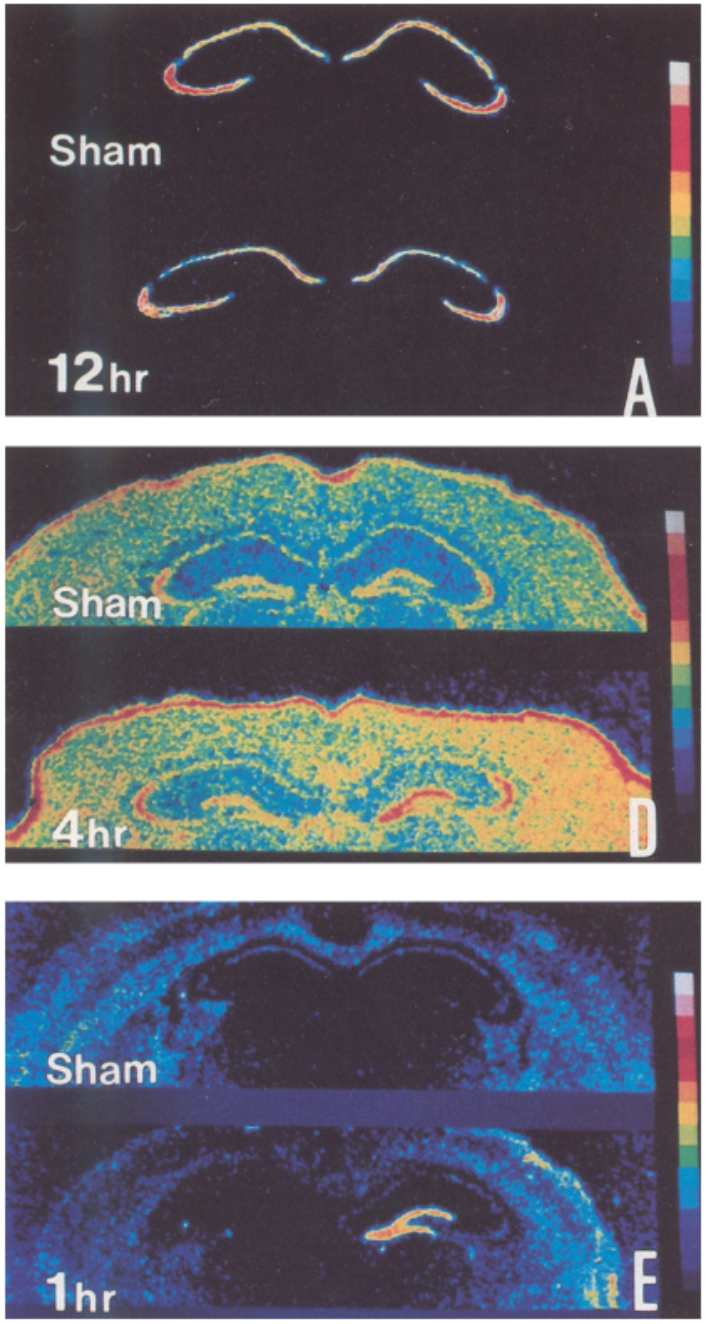
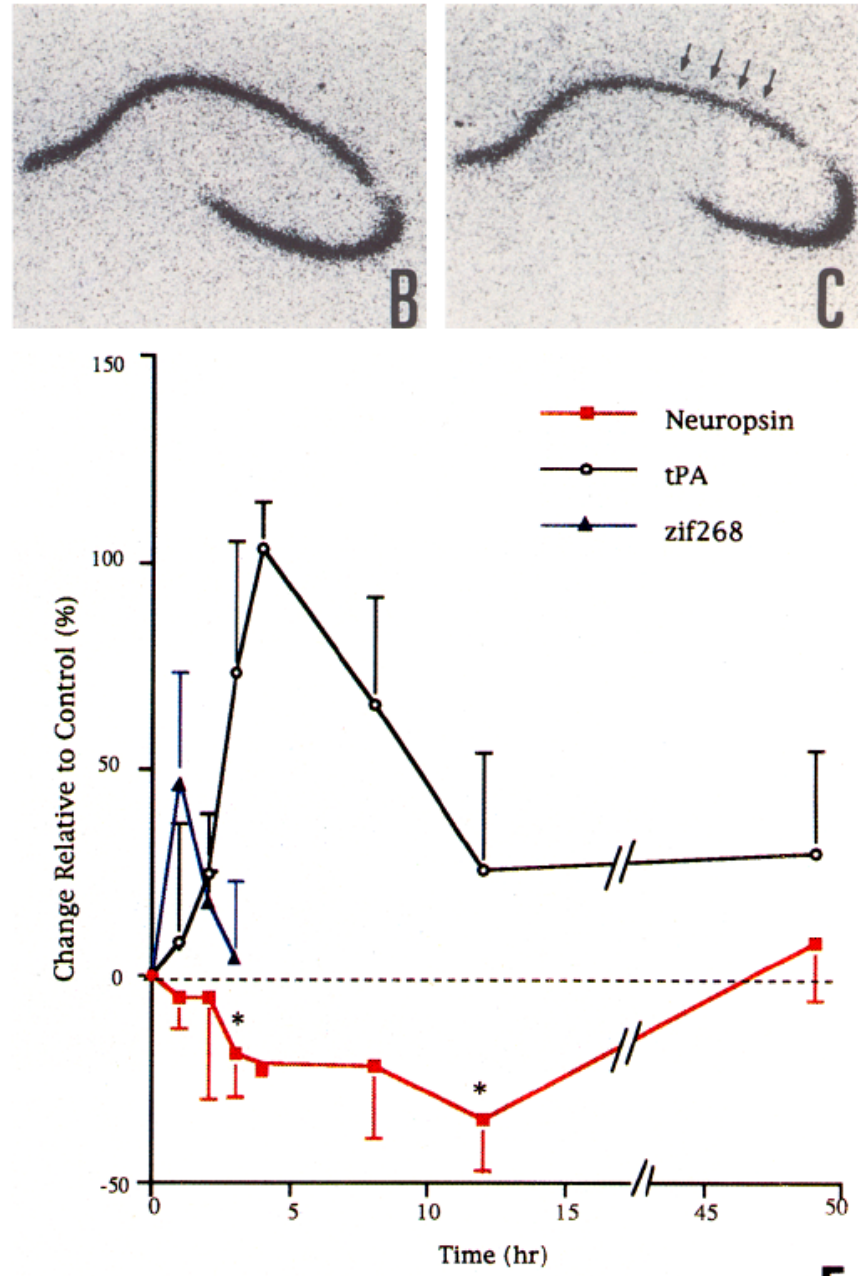

$\mathrm{F}$

Figure 5. Changes in levels of expression of neuropsin, tPA, and zif268 mRNAs after direct hippocampal stimulation. Pseudocolor representation of expression of neuropsin $(A)$, tPA $(D)$, and zif268 $(E)$ mRNAs in stimulated and nonstimulated (sham-treated) mice. $B$ and $C$ represent enlargements of bright-field photographs of sham and $12 \mathrm{hr}$ in A, respectively. Reduction of hybridization signals was apparent in the CA1 subfield (arrows in $C)$. Quantification of signals on autoradiograms was achieved by comparing pixel values of selected areas of interest before and after stimulation: 256 pixels were divided into 16 levels and converted to 16 pseudocolors (color tables are shown on the right-hand side in $A, D$, and $E$ ). Reduction or elevation of the levels of neuropsin $(A)$, tPA $(D)$, and zif268 $(E)$ mRNAs in adjacent sections 12, 4, or 1 hr after stimulation of the ventral hippocampus (right side; $400 \mu \mathrm{A}, 10 \mathrm{~Hz}, 1 \mathrm{msec}$ square pulses for $10 \mathrm{sec}$ ), respectively. $F$, Time course of changes in expression of neuropsin (red line and squares), tPA (black line and circles), and zif268 (blue line and triangles) mRNAs after stimulation of the CA3 subfield of the ventral hippocampus, as quantified by computerized image analysis of autoradiograms. Changes in relative amounts of mRNAs in the CA1 subfield (neuropsin) and the dentate gyrus (tPA and zif268) $1 \mathrm{hr}$ to $48 \mathrm{hr}$ after electrical stimulation. Animals with inserted electrodes but without stimulation were used as controls. All data are given as means \pm SD. ${ }^{*}, P<0.05$.

(Wisden et al., 1990; Abraham et al., 1992; Richardson et al., 1992; Qian et al., 1993). The density of hybridization signals for both neuropsin and tPA mRNAs returned to the control level $48 \mathrm{hr}$ after stimulation. Thus, the same stimulation appears to regulate neuropsin gene expression differently to expression of tPA and zif268.

\section{Effects of kindling on neuropsin gene expression}

Brains from kindled or sham-operated mice were processed for in situ hybridization histochemistry and for signal intensity analysis. Typical afterdischarge in cortical electroencephalograms and progressive development of behavioral seizure scored by a modification of Racine's standard criteria (1972) are shown in Figure $6, A$ and $B$. The time required to evoke stage 4 motor seizure was $22.8 \pm 3.0 \mathrm{~d}$ (mean $\pm \mathrm{SD}$ ), and afterdischarge duration in fully kindled mice was $31.2 \pm 8.1 \mathrm{sec}$ (mean \pm SD).

Table 1 shows that there was a marked elevation of neuropsin mRNA level in CA1, CA3 hippocampal subfields and the lateral amygdaloid nucleus in the kindled mice relative to controls. The elevation was significant as shown by Student's $t$ test compared to the sham-operated control group not only in the side ipsilateral but also contralateral to the amygdala in which stimulation was delivered. Concomitantly, tPA mRNA level was also markedly increased in the CA3 subfield and dentate gyrus. Thus, in the case of kindling, neuropsin and tPA gene expression were both elevated simultaneously. However, zif 268 mRNA expression in the hippocampus was unchanged between kindling and control mice after the last stimulation (data not shown). 


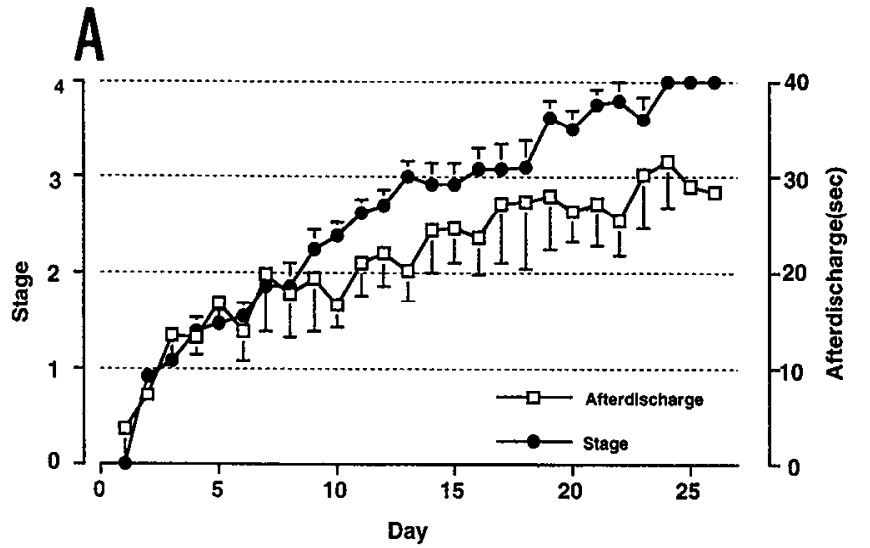

B

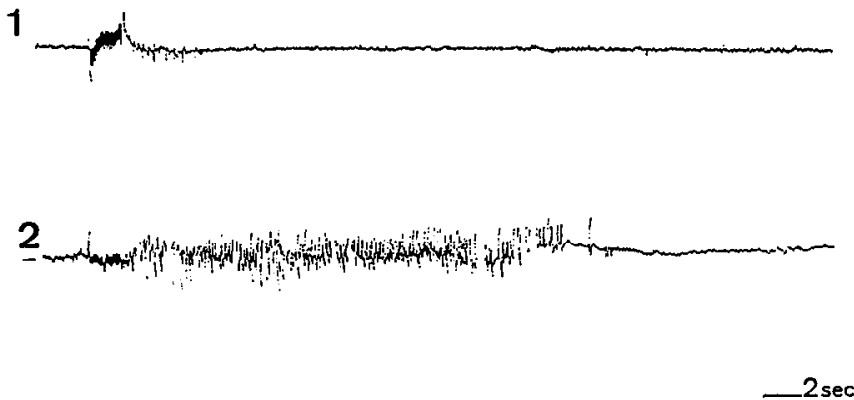

Figure 6. Time course of behavioral stage and duration of afterdischarge during kindling development $(A)$. Values represent mean \pm SEM $(n=$ 11). Scores of behavior are described in Materials and Methods. $B$, Electroencephalograms showing typical afterdischarge of stage 4 kindled mouse. Traces: 1 , early kindling stimulation (stage 1); 2 , expression of a fully kindled seizure manifesting stage 4 seizure.

\section{Discussion}

In the present study, we cloned a novel gene encoding a protein homologous to serine proteases such as NGF- $\gamma$, EGFbp and trypsin, and demonstrated its expression in the limbic brain of mice. Ontogenetic observations showed a similar distribution pattern throughout neonatal to adult development. The highest density of hybridization signals was observed in the hippocampus throughout development. Thus, this protein, which we have designated neuropsin due to its apparent neuronal expression and its sequence homology to trypsin, might function principally in the hippocampal system of mature mice. We used two types of stimulation protocols to explore neuropsin function in the hip- pocampus; direct unilateral electrical stimulation and kindling induced by amygdaloid stimulation. The level of neuropsin mRNA was decreased after direct ventral hippocampal stimulation in the former protocol. In adjacent tissue sections, zif 268 mRNA level increased for 30-90 min after simulation. This might represent inducible LTP, because zif 268 expression shows the greatest correlation with LTP induction of all genes reported to date (Cole et al., 1989; Wisden et al., 1990; Abraham et al., 1992; Richardson et al., 1992). Onset, duration time and phase of induction for neuropsin were late, lasted longer, and were in reverse phase, respectively, compared to those of zif268 and tPA genes. The differences in changes in expression of these genes

Table 1. Induction of neuropsin and tPA mRNAs during kindling

\begin{tabular}{|c|c|c|c|c|}
\hline \multirow[b]{2}{*}{ CNS regions } & \multicolumn{2}{|l|}{ Neuropsin } & \multicolumn{2}{|l|}{ tPA } \\
\hline & $\begin{array}{l}\text { Ipsilateral } \\
\text { side }\end{array}$ & $\begin{array}{l}\text { Contralateral } \\
\text { side }\end{array}$ & $\begin{array}{l}\text { Ipsilateral } \\
\text { side }\end{array}$ & $\begin{array}{l}\text { Contralateral } \\
\text { side }\end{array}$ \\
\hline \multicolumn{5}{|l|}{ Hippocampus } \\
\hline \multicolumn{5}{|l|}{ CA1 subfield } \\
\hline Control & $16.0 \pm 2.1$ & $13.9 \pm 2.4$ & ND & ND \\
\hline Kindling & $23.4 \pm 5.1^{a}$ & $23.2 \pm 4.7^{c}$ & ND & ND \\
\hline Change (\%) & $146.3 \pm 31.9$ & $167.4 \pm 33.6$ & ND & ND \\
\hline \multicolumn{5}{|l|}{ CA3 subfield } \\
\hline Control & $16.5 \pm 0.9$ & $17.4 \pm 1.2$ & $19.8 \pm 2.0$ & $21.1 \pm 2.4$ \\
\hline Kindling & $32.1 \pm 9.8^{c}$ & $27.9 \pm 6.7^{b}$ & $26.3 \pm 5.8^{a}$ & $29.4 \pm 4.9^{c}$ \\
\hline Change $(\%)$ & $194.9 \pm 60.6$ & $160.8 \pm 38.2$ & $134.2 \pm 29.3$ & $139.2 \pm 23.6$ \\
\hline \multicolumn{5}{|l|}{ Dentate gyrus } \\
\hline Control & ND & ND & $21.1 \pm 2.4$ & $22.0 \pm 2.0$ \\
\hline Kindling & ND & ND & $29.4 \pm 4.9^{c}$ & $29.5 \pm 5.4^{c}$ \\
\hline Change (\%) & ND & ND & $139.2 \pm 23.6$ & $134.2 \pm 24.4$ \\
\hline \multicolumn{5}{|l|}{ Amygdala } \\
\hline Control & $3.48 \pm 0.42$ & $3.12 \pm 0.59$ & $13.5 \pm 1.6$ & $13.1 \pm 1.8$ \\
\hline Kindling & $6.78 \pm 1.6$ & $4.47 \pm 0.99^{n}$ & $21.3 \pm 2.5^{c}$ & $17.9 \pm 1.5^{c}$ \\
\hline Change (\%) & $195.0 \pm 46.7$ & $143.5 \pm 31.7$ & $157.9 \pm 18.6$ & $137.0 \pm 11.6$ \\
\hline
\end{tabular}

Data show changes in levels of expression of neuropsin and tPA genes in the hippocampus, dentate gyrus, and amygdala in stage 4 kindled mice. Values represent intensities of hybridization signals measured with a BAS 2000 image anlayzer (Fuji Photo film, Japan). All values are means \pm SD. ND, not determined. The statistical significance of differences between values obtained in kindlcd mice and sham-opcrated controls was determined by Student's $t$ test.

" $P<0.05$.

" $P<0.01$.

c $P<0.005$. 
in response to direct stimulation indicate that the ncuropsin gene and the other genes are regulated independently.

Suiden et al. demonstrated that addition of thrombin, a serine protease, caused retraction of neurite extension of cultured mouse neuroblastoma cells (Suiden et al., 1992). Liu et al. (1994) argued that thrombin may be involved in activity-dependent synapse elimination in their review article. They demonstrated that proteolysis or some receptor-mediated signal transduction mechanism induced by serine protease may be involved in activity-dependent plasticity in the brain. Such protease function may be regulated by some specific protease inhibitors. In short, events associated neuronal plasticity such as neurite extension, retraction, synaptic formation and elimination may be regulated by protease-protease inhibitor function. Neuropsin, a novel serine protease, is localized in the hippocampus in a highly restricted manner. If this protein affects adhesion molecules, extracellular matrix components, and cell-surface receptors of hippocampal pyramidal neurons, activity-dependent function of this protease might be important to regulate the strength of formation of kindling or LTP.

Kindling is a model of epilepsy and neuronal plasticity characterized by the progressive development of electrographic and behavioral seizures. In the hippocampus, the highest density of neuropsin mRNA is localized in the CA1 and CA3 subfields with less intense signals in CA2. No positive hybridization signals were observed in the dentate gyrus. Kindling induced by the perforant path stimulation resulted in elevation of tPA gene expression in the dentate gyrus (Qian et al., 1993). The present study confirmed this result and showed that kindling induced by amygdaloid stimulation also increases tPA gene expression in the dentate gyrus and CA3 subfield of the hippocampus (Table 1). Interestingly, neuropsin mRNA level showed marked elevation by about 1.5-2-fold compared to sham-operated mouse brain CA1 and CA3 subfields both ipsi- and contralateral to the stimulation (Table 1). One possible mechanism to account for this elevation of neuropsin expression in kindling is that this serine protease is a key processing enzyme involved in the regulation of some as yet unidentified trophic factor function to induce kindling.

Protcascs such as tPA might be involved in plasticity (Monard, 1988; Qian et al., 1993; Sappino et al., 1993), cell migration (Moonen et al., 1982), and neurite outgrowth (Monard, 1988; Pittman et al., 1989; Sumi et al., 1992; Sappino et al., 1993). Expression of tPA occurs throughout the whole brain with no region specificity, and the transcript is distributed in both neuronal and non-neuronal elements throughout all brain regions. The limbic brain includes the hippocampal formation and amygdaloid nucleus, the two most important brain regions for the processes of learning, memory and cognitive function. Cerebral functions are known to be organized topographically and systematically. Thus, there is a good correlation between macromolecular localization and functional organization. The localization profile and the activity-dependent marked changes in expression of neuropsin indicate that this gene is likely related to limbic plasticity in events such as learning, memory and cognition.

\section{References}

Abraham WC, Dragunow M, Tate WP (1992) The role of immediate early genes in the stabilization of long-term potentiation. Mol Nenrobiol 5:297-314.

Blaber M, Isackson PJ, Bradshaw RA (1987) A complete cDNA se- quence for the major epidermal growth factor binding protein in the male mouse submandibular gland. Biochemistry 26:6742-6749.

Bliss TVP, Collingridge GL (1993) A synaptic model of memory: long term potentiation in the hippocampus. Nature 361:31-39.

Brenner S (1988) The molecular evolution of genes and proteins: a tale of two serine. Nature 334:528-531.

Cole AJ, Saffan DW, Baraban JM, Worley PF (1989) Rapid increase of an immediate early gene messenger RNA in hippocampal neurons by synaptic NMDA receptor activation. Nature 340:474-476.

Dudek SM, Bear MF (1992) Homosynaptic long-term depression in area CA1 of hippocampus and effects of $N$-methyl-D-aspartate receptor blockade. Proc Natl Acad Sci USA 89:4363-4367.

Dugich-Djordjevic MM, Tocco G, Willoughby DA, Najm I, Pasinetti G, Thompson RF, Baudry M, Lapchak PA, Hefti F (1992) BDNF mRN $\Lambda$ expression in the developing rat brain following kainic acidinduced seizure activity. Neuron 8:1127-1138.

Ernfors P, Bengzon J, Kokaia Z, Persson H, Lindvall O (1991) Increased levels of messenger RNAs for neurotrophic factors in the brain during kindling epileptogenesis. Neuron 7:165-176.

Evans BA, Richards RI (1985) Genes for the alpha and gamma subunits of mouse nerve growth factor are contiguous. EMBO J 4:133138.

Isackson PJ, Huntsman MM, Murray KD, Gall CM (1991) BDNF mRNA is increased in adult rat forebrain after limbic seizure: temporal patterns of induction distinct from NGF. Neuron 6:937-948.

Kirkwood A, Dudek SM, Gold JT, Aizenman CT, Bear MF (1993) Common forms of synaptic plasticity in the hippocampus and neocortex in vitro. Science 260:1518-1521.

Kozak M (1986) Selection of translational start sites in eukaryotic mRNAs. In: Current communications in molecular biology (Mathews MB, ed), pp 35-41. Cold Spring Harbor, NY: Cold Spring Harbor Laboratory.

Kyte J, Doolittle RF (1982) A simple method for displaying the hydropathic character of a protein. J Mol Biol 157:105-132.

Liu Y, Fields RD, Fizgerald S, Festoff BW, Nelson PG (1994) Proteolytic activity, synapse elimination, and the Hebb synapse. J Neurobiol 25:325-335.

Mackler SA, Brooks BP, Ebelwine JH (1992) Stimulus-induced coordinate changes in mRNA abundance in single postsynaptic hippocampal CA1 neurons. Neuron 9:539-548.

Madison EL, Kobe A, Gething M-J, Sambrook JF, Goldsmith EJ (1993) Converting tissue plasminogen activator to a zymogen: a regulatory triad of Asp-His-Ser. Science 262:419-421.

Marshall RD (1972) Glycoproteins. Annu Rev Biochem 41:673-702.

McNamara O (1988) Pursuit of the mechanisms of kindling. Trends Neurosci 11:33-36.

Monard D (1988) Cell-derived proteases and protease inhibitors as regulators of neurite outgrowth. Trends Neurosci 11:541-544.

Montarolo PG, Goelet P, Castelucci VF, Morgan J, Kandel ER and Schacher S (1986) A critical period for macromolecular synthesis in long-term heterosynaptic facilitation in Aplysia. Science 234:12491254.

Moonen G, Grau-Wagemans M, Selak I (1982) Plasminogen activatorplasmin system and neuronal migration. Nature 298:753-755.

Mulkey RM, Malenka RC (1992) Mechanisms underlying induction of homosynaptic long-term depression in area CA1 of the hippocampus. Neuron 9:967-975.

Nedivi E, Hevroni D, Naot D, Israeli D, Citri Y (1993) Numerous candidate plasticity-related genes revealed by differential cDNA cloning. Nature 363:718-722.

Pittman RN, Ivins JK, Buettner HM (1989) Neuronal plasminogen activators: cell surface binding sites and involvement in neurite outgrowth. J Neurosci 9:4269-4286.

Qian Z, Gilbert M, Colicos MA, Kandel ER, Kuhl D (1993) Tissueplasminogen activator is induced as an immediate-early gene during seizure, kindling and long-term potentiation. Nature 361:453-457.

Racine RJ (1972) Modification of seizure activity by electrical stimuIation. II. Motor seizures. Electroencephalogr Clin Neurophysiol 32: 281-294.

Richardson CL, Tate WP, Mason SE, Lawlor PA, Dragunow M, Abraham WC (1992) Correlation between the induction of an immediate early gene, zif/268, and long-term potentiation in the dentate gyrus. Brain Res 580:147-154

Rickles RJ, Dallow AL, Strickland S (1989) Differentiation-responsive elements in the 5 region of the mouse tissue plasminogen activator 
gene confer two-stage regulation by retinoic acid and cyclic AMP in tetracarcinoma cells. Mol Cell Biol 9:1691-1704.

Rocamora N, Paracios JM, Mengod G (1992) Limbic seizures induce a differential regulation of the expression of nerve growth factor, brain-derived neurotrophic factor and neurotrophin-3, in the rat hippocampus. Mol Brain Res 13:27-33.

Sappino A-P, Madani R, Huarte J, Belin D, Kiss JZ, Wohlwent A, Vassalli J-D (1993) Extracellular proteolysis in the adult murine brain. J Clin Invest 92:679-685.

Schuman EM, Madison DV (1994) Locally distributed synaptic potentiation in the hippocampus. Science 263:532-536.

Sekitani M, Shiosaka S, Kuriyama H, Lee Y, Ikeda M, Tohyama M (1990) Transient expression of somatostatin mRNA in the auditory system of neonatal rat. Mol Brain Res 7:177-181.

Suiden HS, Stone SR, Hemmings BA, Monard D (1992) Thrombin causes neurite retraction in neuronal cells through activation of cell surface receptors. Neuron 8:363-375.

Sumi Y, Dent MAR, Owen DE, Seeley PJ, Morris RJ (1992) The expression of tissue and urokinase-type plasminogen activators in neural development suggests different modes of proteolytic involvement in neuronal growth. Development 116:625-637.

Wanaka A, Johnson EM, Milbrandt J (1990) Localization of FGF receptor mRNA in the adult rat central nervous system by in situ hybridization. Neuron 5:267-281.

Wisden W, Errington ML, Williams S, Dunnett SB, Waters C, Hitchcock D, Evans G, Bliss TVP, Hunt SP (1990) Differential expression of immediate early genes in the hippocampus and spinal cord. Neuron 4:603-614.

Worley PF, Bhat RV, Baraban JM, Erickson CA, McNaughton BL, Barnes A (1993) Thresholds for synaptic activation of transcription factors in hippocampus: correlation with long-term enhancement. $\mathbf{J}$ Neurosci 13:4776-4788. 